know that a further report, adapting the syllabuses in greater detail for use in secondary modern schools of varied types of area, is already in production.

\section{Fossil Fauna in Norfolk}

DrscoverIes of no little interest to palæontologists and archæologists are reported from Norfolk. During the past winter and early spring, the effects of marine erosion on the cliffs around the coast have been severe, causing much local uneasiness. In compensation, as a result of this tidal action, early quaternary deposits at the base of the cliffs and on the foreshore have been laid bare to an exceptional degree. At Mundesley, in particular, the Cromer Forest Bed is exposed more extensively than has occurred for a very long period and a number of discoveries have followed. Early in May, a fossil bone protruding at the base of the cliff was observed by Mr. E. A. Livermore of Mundesley. On extraction, this proved to be the major portion, a little more than three feet in length, of an elephant's tusk. It has since been identified as belonging to the extinct straight-tusked elephant, Elephas antiquus. A few days later, Mr. Livermore also recovered from close to the position of his first find part of a tooth, about six inches in length, of an elephant of the same species. Further discoveries were two fragments of bone, the tips of an elephant's femur and tibia respectively. A remarkable tooth, which belongs to $E$. meridionalis, also from the Cromer Forest bed at Mundesley, has been found by Mr. A. Savin of Cromer. It is complete, and weighs twenty-five pounds. With one exception, a tooth of twenty-six pounds, it is said to be the largest meridionalis tooth recorded.

The estuarine deposits of the Cromer Forest bed series at Mundesley, it will be remembered, have yielded in the past a rich fossil mammalian fauna, of which a large proportion, more than 70 per cent, belongs to extinct species. They include, in addition to the two elephants mentioned above, Hycena striata, Rhinoceros etruscus, the sabre-toothed tiger (Machcerodus latidens), which is also recorded from Kent's Cavern, Torquay, and the hippopotamus, which appears here for the first time. As a whole, the mammalian fauna is from a warm-temperate climate, whereas the marine is regarded as indigenous and on the whole is arctic. In relation to man, the Cromer Forest Bed equates with the developed Abbevillian (Chellean) industry.

\section{Institute of Fuel}

Those who can look back to the beginning of the century cannot fail to be impressed by the changes which have taken place in connexion with the supply of fuel. The excellent-and what now appears to be cheap-coal was abundant : cost of fuel might appear to be a negligible factor in the production of manufactured products. Advocates of fuel saving or smoke abatement were voices crying in the wilderness : their messages were of no concern to the State and even unwelcome to the fuel industries. Two great wars-especially the last one-have produced the great change, revealed nowhere more clearly than in the development of the Institute of Fuel. On April 17, Dr. E. W. Smith, in his presidential address, said that the Institute, which in 1939 after a modest life of twelve years had gathered about one thousand members, had by 1946 reached in numbers about two thousand six hundred. This is a measure of the growing interest by the technologists themselves. It is a measure of the rising importance of fuel conservation for a long time to come. The Institute is devoting much attention to the spread of better understanding about fuel and its utilisation. Dr. Smith said that this should begin with children, who should be taught early at school the elements of the science of combustion, so that they are already 'fuel conscious' before embarking on the business of life.

The Institute of Fuel hopes in the near future to reach the dignity of a chartered body. In addition to the publication of an important technical journal, the Institute has started a scheme to encourage the public education in fuel technology in all branchesfrom the operative to the research worker. In this, the Institute is in co-operation with the Ministry of Fuel and Power, and, on the examination side, with the City and Guilds Institute. All this activity can be understood if it be remembered that, in future, domestic arrangements must become less primitive and more efficient. Recognition of the essential worth of fuel as a national possession must assert an influence in all walks of life.

\section{Association of Special Libraries and Information Bureaux: Northern Branch}

Aт the conference in Manchester on May 8 arranged by the Association of Special Libraries and Informa. tion Bureaux to discuss industrial information services, a statement regarding the proposed formation of a Northern Branch of the Association was made by $\mathrm{Mr}$. R. Brightman, librarian, Imperial Chemical Industries, Ltd., Dyestuffs Division, and chairman of the provisional committee formed early in the year for that purpose. The desire of many members of the Association for regular meetings in the northern area, as well as for a conference in that area, has been frequently expressed at recent annual conferences; and in view of the fact that a heavy proportion of the industrial membership of the Association is concentrated in an area lying north and west of a line drawn roughly from the Humber through Nottingham, Leicester, Birmingham to Bristol, the Committee has in mind something much wider than the mere revival of the Lancashire and Cheshire Branch which functioned during the period 1931-36. The committee contemplates, instead of a series of meetings in any one town, a programme of meetings in different centres, preferably not more than a couple of meetings in the year, which might be arranged in such places as Manchester, Liverpool, Harrogate, Keighley, Nottingham, etc., and cover subjects meeting the needs of the works' librarian in particular. It is hoped that the Branch will keep in close touch with such developments as the lectures on classification and cataloguing arranged at the College of Technology, Manchester, by the NorthWestern Branch of the Library Association, and other developments which may provide training for those entering on a career of librarianship in indwetry.

A meeting to constitute such a Northern Bralish will be held at the Manchester Central Library, Peter Square, on June 27 at 3 p.m. Mr. R. Brightman will preside, and after the formal business and election of a committee, Miss M. Exley, librarian of the Commercial, Science and Technological Libraries, Sheffield, will speak on "Co-operation between Libraries in the Northern Region". The provisional committee, in retiring, is suggesting a further meeting of the Branch at Liverpool in the autumn and a one-day conference at Sheffield in the spring of 1947. The honorary secretary is Miss L. Wolff, Hexagon House, Blackley, Manchester. 